\title{
Pengembangan Budaya Organisasi Sekolah Swasta Unggul
}

\author{
Putri Wulandari; Piter Joko Nugroho \\ FKIP Universitas Palangka Raya \\ Jalan Yos Sudarso Kampus UPR Tunjung Nyaho, Palangka Raya \\ putriwulandarimp5@gmail.com
}

Article received: February 2020; revised : June 2020 ; accepted : July 2020

DOI : 10.17977/um025v4i32020p240

\begin{abstract}
This study aims to describe the development of excellent private middle school (SMPS) organizational culture in Palangkaraya City, viewed from aspects: (1) positive values that underlie the development of school organizational culture, (2) the strategy of internalizing positive values in the development of school organizational culture, (3) supporting and obstacles factors in the development of school organizational culture, and (4) the role of stakeholders in supporting the development of school organizational culture. This study used qualitative approach with case study design. The subjects of this study were the founder of the Golden Christian School (GCS) SMPS, the school principal, teachers, and school stakeholders. Data collected through observation, in-depth interviews and documentation studies. Data analysis techniques using interactive model is through data reduction, data presentation, conclusions drawing, and data verification. Validation of data in this study uses credibility, transferability, dependability and confirmability. The results of this study showed that the school organizational culture in SMSPS GCS was developed by basing on the values of Christianity as the main foundation in shaping the character and culture of school organizations. Through internalization strategies that are realized in various school policies and programs, positive values that are believed by schools to be embedded within students which ultimately shape school organizational culture and are able to make SMPS GCS as the excellent private school in Palangka Raya City.
\end{abstract}

Keywords: school organization culture; excellent schools

Abstrak: Penelitian ini bertujuan untuk mendeskripsikan pengembangan budaya organisasi Sekolah Menengah Pertama Swasta (SMPS) unggul di Kota Palangka Raya, dilihat dari aspek: (1) nilai-nilai positif yang mendasari pengembangan budaya organisasi sekolah, (2) strategi internalisasi nilai-nilai positif dalam pengembangan budaya organisasi sekolah, (3) faktor pendukung dan kendala dalam pengembangan budaya organisasi sekolah, dan (4) peran stakeholder dalam mendukung pengembangan budaya organisasi sekolah. Penelitian ini menggunakan pendekatan kualitatif dengan rancangan studi kasus. Subjek penelitian ini adalah Pendiri yayasan SMPS Golden Christian School (GCS), Kepala sekolah, Guru, dan Stakeholder sekolah. Data penelitian dikumpulkan melalui observasi, wawancara mendalam dan studi dokumentasi. Teknik analisis data menggunakan interactive model reduksi data, penyajian data, penarikan kesimpulan, dan verifikasi data. Pengabsahan data dalam penelitian ini menggunakan credibility, transferability, dependability dan confirmability. Hasil penelitian menunjukan bahwa budaya organisasi sekolah di SMPS GCS dikembangkan dengan mendasarkan pada nilai-nilai ajaran agama Kristen sebagai landasan utama dalam pembentukan karakter dan budaya organisasi sekolah. Melalui strategi-strategi internalisasi yang direalisasikan dalam berbagai kebijakan dan program sekolah, nilai-nilai positif yang diyakini sekolah tertanam dan melekat dalam diri peserta didik yang pada akhirnya membentuk budaya organisasi sekolah serta mampu menjadikan SMPS GCS sebagai sekolah swasta unggul di Kota Palangka Raya.

Kata Kunci: budaya organisasi sekolah; sekolah unggul 
Pendidikan pada hakikatnya merupakan proses pematangan kualitas hidup manusia. Pendidikan dapat pula diartikan sebagai upaya transmisi budaya dalam bentuk informasi spesifik melalui proses mental dan rasionalitas yang mengarahkan peserta didik untuk memperoleh pengalaman dalam rangka mencapai kemampuan tertentu serta martabat yang mulia melalui transmission of knowledge, skills, values, and culture (Sonhadji, 1994). Dalam pendidikan aspek-aspek rasionalitas, martabat, etika dan estetika sangat ditekankan karena anak-anak sekarang adalah pemimpin dan pelaku-pelaku perjalanan bangsa Indonesia di masa depan (Sonhadji, 2012). Melalui proses tersebut manusia diharapkan dapat memahami arti dari hakikat hidup, serta untuk apa dan bagaimana menjalankan tugas hidup dan kehidupan manusia secara benar (Hermino, 2013); dan oleh karena itu pendidikan yang baik adalah usaha yang berhasil membawa semua peserta didik kepada tujuan tersebut. Apa yang diajarkan hendaknya dipahami sepenuhnya oleh semua peserta didik (Nasution, 1982), sehingga fokus pendidikan hendaknya diarahkan pada pembentukan kepribadian/karakter unggul dengan menitikberatkan pada proses pematangan kualitas logika, hati, akhlak, dan keimanan manusia/peserta didik (Amalia dkk, 2017).

Sekolah sebagai lembaga pendidikan tempat berlangsungnya proses pendidikan merupakan institusi yang kompleks, bahkan paling kompleks diantara keseluruhan institusi sosial (Hanson dalam Rahayu dkk, 2019). Sebagai institusi yang kompleks, sekolah tidak akan menjadi baik dengan sendirinya, melainkan melalui proses peningkatan tertentu (Bafadal, 2003). Dewi (2015) dalam penelitiannya menemukan bahwa kualitas pendidikan yang dicapai sekolah merupakan salah satu hasil dari budaya sekolah yang kuat. Budaya sekolah yang kuat memiliki peranan penting dalam mewujudkan peningkatan kualitas sekolah dan menjadikan sekolah yang efektif (Hotimah \& Hariyati, 2009). Sekolah sebagai suatu bentuk organisasi mempunyai budaya tersendiri yang membentuk corak dari sistem yang utuh dan khas. Budaya organisasi sekolah sebagai kerangka kerja kognitif yang terdiri sikap, nilai-nilai norma perilaku dan harapan yang diterima bersama oleh anggota organisasi merupakan serangkaian karakteristik inti yang dihargai secara kolektif oleh anggota organisasi (Greenbeg \& Baron dalam Wibowo, 2010).

Depdiknas (2003) serta Siswanto (2017) menjelaskan peningkatan kualitas pendidikan sekolah pada dasarnya dapat dapat dibangun melalui 2 (dua) strategi utama, yaitu strategi yang berfokus pada: (1) dimensi struktural, dan (2) dimensi kultural. Penerapan strategi secara struktural sudah sering dilakukan melalui berbagai pengaturan, rekayasa sistem penyampaian informasi yang relevan dengan tuntutan dan kebijakan namun hasilnya dipandang belum cukup memuaskan (Atika dkk, 2019). Oleh sebab itu agar mutu pendidikan sekolah meningkat selain dilakukan secara konvensional perlu pula dilakukan dengan pendekatan inkonvensional, yaitu melalui strategi yang berfokus pada dimensi kultural sebagai salah satu faktor yang menentukan peningkatan mutu sekolah (Hafidhuddin dan Tanjung, 2003). Berbagai studi lainnya juga menunjukkan bahwa strategi yang bersifat budaya atau dinamakan pengembangan budaya sekolah berpengaruh besar terhadap perilaku belajar para peserta didik di sekolah. Studi yang dilakukan Jones (1996) pada sekolah-sekolah di Toronto menunjukan sekolah-sekolah berprestasi pada umumnya dapat dikenali dari budaya organisasi sekolah yang kuat dan positif yang pada akhirnya bermuara pada pencapaian tujuan sekolah. Budaya sekolah yang unggul merupakan salah satu unsur yang penting dalam mendukung peningkatan prestasi dan mutu pendidikan (Husni, 2015).

Pendidikan tidak dapat dipisahkan dari keseluruhan masyarakat atau dengan kata lain merupakan sebagian dari kebudayaan (Tilaar, 2000). Kebudayaan dan pendidikan memiliki hubungan timbal balik, sebab kebudayaan dapat dilestarikan dan dikembangkan dengan jalan mewariskan kebudayaan dari generasi ke generasi penerus melalui pendidikan, baik secara formal, informal dan non formal. Sebaliknya bentuk, ciri-ciri dan pelaksanaan pendidikan ikut ditentukan pula oleh kebudayaan masyarakat dimana proses pendidikan itu berlangsung (Tirtahardja \& Sulo, 2005). Oleh karena itu sekolah memiliki peranan yang besar dalam pengembangan budaya dan pendidikan karakter karena peran sekolah adalah sebagai pusat pembudayaan melalui pendekatan pengembangan budaya sekolah (school culture) (Kosim, 2019).

Upaya peningkatan kualitas sekolah harus dimulai dari internal sekolah itu sendiri, yaitu harus memperhatikan nilai nilai yang hidup sebagai budaya sekolah. Budaya merujuk pada suatu sistem nilai, kepercayaan dan norma-norma yang diterima secara bersama, serta dilaksanakan dengan penuh kesadaran sebagai perilaku alami, yang dibentuk oleh lingkungan yang menciptakan pemahaman yang sama diantara seluruh unsur dan personil sekolah baik itu kepala sekolah, guru, staf, peserta didik dan 
jika perlu membentuk opini masyarakat yang sama dengan sekolah (Sudrajat, 2010). Budaya sekolah merupakan sesuatu yang dibangun dari hasil pertemuan antara nilai-nilai (values) sekolah berdasarkan filosofis pendiri sekolah, nilai-nilai yang dianut kepala sekolah serta seluruh personil sekolah lainnya. Nilai-nilai tersebut dibangun oleh pikiran pikiran manusia yang ada dalam sekolah. Pertemuan pikiranpikiran manusia tersebut kemudian menghasilkan apa yang disebut Kasali (2007) sebagai "pikiran organisasi". Dari pikiran organisasi itulah kemudian muncul dalam bentuk nilai-nilai yang diyakini bersama, dan kemudian nilai-nilai tersebut akan menjadi bahan utama "pembentuk" budaya sekolah. Dari budaya tersebut muncul dalam berbagai simbol dan tindakan yang kasat indra yang dapat diamati dan dirasakan dalam kehidupan sekolah.

Penerapan dan pengelolaan kultur sekolah sebagai ciri khas, karakter dan citra sekolah di masyarakat yang tepat akan mempunyai pengaruh yang berarti dalam aktivitas belajar peserta didik, maupun dalam mempengaruhi guru untuk melakukan pekerjaan yang lebih efisien dan efektif untuk mencapai kinerja guru yang baik sekaligus pula mendukung pencapaian sekolah yang efektif dan bermutu (Bukhori \& Anita, 2009; Hotimah \& Hariyati, 2009) dan pada akhirnya hal-hal positif tersebut akan menumbuhkan kepercayaan (trust) masyarakat terhadap sekolah (Atika dkk, 2019). Begitu pentingnya peran budaya organisasi sekolah dalam membangun dan memelihara komitmen seluruh personil sekolah sehingga kelangsungan mekanisme dan fungsi yang telah disepakati akan membantu dalam merealisasikan berbagai tujuan sekolah. Hal itu tidak hanya membawa dampak keuntungan bagi organisasi sekolah secara umum, namun juga akan mampu meningkatkan kemauan, kesetiaan, kebanggaan serta lebih jauh menciptakan efektivitas sekolah.

Penelitian ini didasari oleh fenomena sekolah swasta unggul berbasis agama Kristen yang berusia relatif sangat muda (beroperasi sejak tahun 2016) namun memiliki berbagai macam prestasi (akademik dan non akademik) dan mendapatkan kepercayaan (trust) yang sangat baik dari masyarakat dilihat dari tingginya input (animo) masyarakat untuk menyekolahkan anaknya pada sekolah tersebut. Atas dasar fenomena tersebut peneliti tertarik untuk mengkaji lebih dalam tentang pengembangan budaya organisasi sekolah di SMP Golden Christian School (GCS) Palangka Raya.

\section{METODE}

Penelitian ini dilakukan di SMPS GCS Palangka Raya yang merupakan sekolah swasta unggul di kota Palangka Raya. Penelitian ini merupakan kualitatif dengan rancangan studi kasus. Penelitian ini menggunakan metode penelitian kualitatif dengan rancangan penelitian studi kasus (case studies), yaitu sesuatu penelitian kualitatif yang berusaha menemukan makna, menyelidiki proses, dan memperoleh pengertian dan pemahaman yang mendalam dari individu, kelompok atau situasi (Emzir, 2014)

Subjek penelitian ini adalah Pendiri Yayasan Golden Christian School (GCS) sebagai informan kunci, Kepala Sekolah, Guru, serta para Stakeholder sekolah. Objek penelitian tentang pengembangan budaya organisasi sekolah. Fakta dan informasi diperoleh melalui teknik wawancara mendalam, pengamatan, dan studi dokumentasi. Instrumen penelitian adalah peneliti yang dibantu dengan pedoman wawancara, pedoman pengamatan, dan pedoman dokumentasi

Sementara itu, teknik analisis data dengan menggunakan interactive model yaitu melalui reduksi data, penyajian data, penarikan kesimpulan, dan verifikasi data. Pengumpulan data merupakan tahap penting dalam penelitian karena perolehan data yang diperoleh di lapangan digunakan dalam menganalisis hasil penelitian. Ada beberapa teknik yang digunakan oleh peneliti dalam penelitian ini, yaitu: wawancara mendalam, observasi partisipasi, dan studi dokumentasi.

Analisis data menggunakan model alir, sebagaimana disarankan oleh Miles, Huberman, dan Saldan (2014), yaitu: melalui data reduction, data display, dan conclusions drawing/verifying. Fakta dan informasi sebagai suatu data perlu diuji keabsahannya. Untuk itu dalam penelitian ini peneliti melakukan pengujian keabsahan data dengan menggunakan tingkat credibility, transferability, dependability, dan confirmability. 


\section{HASIL DAN PEMBAHASAN}

\section{Nilai-nilai Positif yang Mendasari Pengembangan Budaya Organisasi Sekolah}

Nilai-nilai positif yang mendasari dalam pengembangan budaya organisasi sekolah di SMP GCS merupakan nilai-nilai yang bersumber dari ajaran agama Kristen yang bertintikan taat dan takut akan Tuhan. Nilai-nilai positif dalam ajaran agama Kristen tersebut menjadi inti ajaran yang mengatur seluruh aspek kehidupan di sekolah dimana seluruh warga sekolah termasuk peserta didik wajib untuk melaksanakan dan mentaatinya. Sesuai dengan visi dan misi sekolah yaitu menghasilkan calon pemimpin masa depan yang takut akan Tuhan dan berkarater mulia, maka nilai-nilai positif ajaran agama Kristen menjadi nilai dasar yang ditanamkan untuk membentuk karakter para peserta didik. Nilai-nilai positif tersebut meliputi: (1) Mengasihi Tuhan dan sesama manusia, ditujukan agar para peserta didik dapat mengasihi Tuhan dengan segenap hati, jiwa dan pikiran serta mentaati segala perintah Tuhan yang pada akhirnya dengan mengasihi Tuhan juga diharapkan dapat pula mengimplementasikan bentuk kasih tersebut kepada sesama manusia dengan tidak memandang latar belakang status sosial ekonomi serta faktor-faktor lainnya; (2) Berkarakter mulia, ditujukan agar para para peserta didik memiliki sifat dan sikap yang tulus, tidak egois, menghormati orang lain, murah hati dan rendah hati, jujur dalam setiap perkataan maupun tindakan, memberikan semangat kepada orang lain serta selalu bersyukur dan memiliki iman yang sejati, (3) Disiplin, cakap dan kreatif, ditujukan agar para peserta didik patuh terhadap peraturan dan tata tertib sekolah, berwawasan luas dan kreatif, berpenampilan rapi dan bersih, memperhatikan dan mematuhi apa yang di ajarkan oleh guru maupun orang tua serta berbagai peraturan dan budaya sekolah, rajin dan cakap dalam mengerjakan tugas dan kewajibannya, bepikir secara kritis, memiliki kemampuan dan berani menciptakan sesuatu yang baru, rajin belajar menuntut ilmu, serta menggunakan waktu secara efektif dan efesien untuk peningkatan kualitas diri; dan (4) Mandiri dan bertanggung jawab, ditujukan agar peserta didik memiliki kepercayaan diri dengan kemampuan dirinya dan tidak bergantung dengan orang lain, dapat menjadi teladan bagi orang lain, belajar dengan penuh semangat dan bertanggung jawab, percaya diri dan disiplin, aktif dalam bidang keagamaan maupun bidang kemasyarakatan, memiliki daya tahan dan daya juang untuk meraih cita-cita sebagai pemimpin di masa depan, serta dapat mengikuti kemajuan teknologi secara bijak dan dapat bermanfaat.

Budaya sekolah merupakan sekumpulan nilai yang melandasi perilaku, kebiasaan, keseharian dan simbol-simbol yang dipraktikkan oleh seluruh warga sekolah. Budaya sekolah juga merupakan ciri khas, karakter atau watak dan citra sekolah di masyarakat luas. Tanpa budaya sekolah yang kuat dan bagus akan sulit menerapkan pendidikan karakter bagi anak sehingga siapapun yang masuk dan bergabung di sekolah yang memiliki budaya sekolah yang "mapan" hampir secara otomatis akan mengikuti tradisi yang berlaku di sekolah (Hidayat, 2010).

Temuan penelitian tentang nilai-nilai positif yang mendasari dalam pengembangan budaya organisasi sekolah sejalan pendapat Muhaimin (2003) bahwa pelaksanaan budaya religius di sekolah mempunyai landasan kokoh yang normatif religius maupun konstitusional sehingga tidak ada alasan bagi sekolah untuk mengelak dari usaha tersebut. Dengan tertanamnya nilai-nilai budaya religius pada diri peserta didik akan memperkokoh iman peserta didik dan aplikasi dari nilai-nilai tersebut dapat tercipta dari lingkungan di sekolah. Oleh karena itu membangun budaya religius sangat penting dan akan mempengaruhi sikap, sifat dan tindakan peserta didik secara tidak langsung (Bakri, 2010).

Muhaimin, dkk (2009) memaparkan terbangunnya pikiran, perkataan, dan tindakan peserta didik yang berdasarkan nilai-nilai ke-Tuhanan yang bersumber dari ajaran agama yang dianut, diharapkan peserta didik dapat benar-benar memahami dan mengamalkan ajaran agama dalam kehidupan seharihari. Seseorang harus memiliki karakter yang mencerminkan manusia yang beragama, tidak hanya sebatas pengakuannya saja tetapi harus mempraktikkannya dalam kehidupan sehari-hari sesuai dengan ajaran agama yang dianutnya. Nilai religius merupakan nilai yang paling penting dalam kehidupan manusia karena apabila seseorang dapat mencintai Tuhannya, kehidupannya akan penuh kebaikan apalagi jika kecintaan kepada Tuhan juga disempurnakan dengan mencintai dan mengasihi sesama manusia dan semua ciptaan-Nya serta menjalankan apa yang diperintahkan oleh Tuhan maka seseorang yang mempunyai karakter tersebut akan berusaha berperilaku penuh cinta dan kebaikan (Samsuri, 2011). 


\section{Strategi Internalisasi Nilai-Nilai Positif dalam Pengembangan Budaya Organisasi Sekolah}

Dalam upaya menginternalisasikan nilai-nilai positif dalam ajaran agama Kristen untuk menghasilkan calon pemimpin masa depan yang takut akan Tuhan dan berkarakter mulia, strategi yang dilakukan oleh SMP GCS dilaksanakan dengan cara: (1) Pembiasaan ibadah pagi sebelum pembelajaran dimulai yang dilakukan melalui: (a) mengumpulkan seluruh peserta didik dalam ruangan aula sekolah untuk melaksanakan ibadah (chapel) pagi, (b) menyanyikan lagu puji-pujian, (c) merenungkan firman Tuhan, dan (d) berdoa mengucap syukur atas segala kebaikan yang diberikan oleh Tuhan atas nafas, kesehatan dan kekuatan serta melakukan doa bersama agar proses pembelajaran dapat berjalan dengan baik dan lancer; (2) Pemajangan simbol-simbol kekristenan dan kata-kata motivasi, antara lain: (a) salib yang merupakan lambang pengenal yang menandakan agama Kristen, (b) gambar dan tulisan motivasi, seperti: : "Jadilah pemimpin demi Tuhan", "Jangan Menyerah", "Hal yang memalukan bukanlah ketika kau jatuh, tetapi ketika kau tidak mau bangkit lagi", "Berdoalah untuk apa yang anda kerjakan, bekerjalah untuk apa yang anda doakan", "Hidup itu penuh dengan tantangan, jangan menghindar tapi hadapilah", "Rajinlah membaca buku karena buku adalah jembatan ilmu",," Bersuka citalah senantiasa dalam nama$\mathrm{Ku}$ ", "Hati yang ceria dan penuh kedamaian, akan meningkatkan kesehatan tubuh dan member umur Panjang"(Filipi 4:4), "You'll find that life is still worth while if you just smile. It's a new dawn, It's a new day" (Golden Christian School), dan (c) simbol-simbol kekristenan lainnya yang bertujuan untuk mengingatkan dan memotivasi peserta didik agar selalu mengenal dan dekat dengan Tuhannya melalui firman-Nya; (3) Program Bible Camp dan Family Day, yaitu program sekolah yang bertujuan untuk menanamkan nilai-nilai rohani dan kepemimpinan melalui pendekatan yang menyeimbangkan antara pengajaran, penyembahan, persekutuan, rekreasi dan ekspresi. Program Bible Camp ini dilaksanakan setiap 1 tahun sekali dimana seluruh peserta didik diajak menuju tempat rekreasi, untuk melaksanakan kegiatan ibadah tentang firman Tuhan sembari melakukan rekreasi dan berolahraga/bermain. Sedangkan program Family Day diselenggarakan untuk membangun hubungan yang harmonis antara orang tua, peserta didik dan sekolah sekaligus pula mengajarkan tanggungjawab dan kepekaan para orang tua bahwa tumbuh kembang anak harus menyelaraskan hubungan yang harmonis antara pihak sekolah dan keluarga. Melalui program tersebut para orang tua semakin memahami bagaimana cara mendidik anak mereka agar kelak dapat tumbuh dan berkembang dalam segala aspek secara optimal. Kegiatan tersebut dilaksanakan 2 kali dalam 1 tahun, dimana dalam kegiatan tersebut antara orang tua dan anak berkolaborasi dalam berbagai lomba dan aktivitas yang dilaksanakan di lingkungan sekolah; dan (4) Penegakan peraturan dan tata tertib sekolah direalisasikan dalam buku pedoman sekolah dan buku tata tertib sekolah yang dalam implementasinya dikawal oleh tim Satuan Tugas (Satgas) pengawal budaya sekolah. Kepala sekolah membentuk tim Satgas pengawal budaya sekolah yang terdiri dari unsur Wakil Kepala Sekolah bidang Kesiswaan, Guru Bimbingan Konseling (BK) serta Petugas Keamanan Sekolah (security) yang bertugas melakukan monitoring dalam mengawal jalannya kehidupan peserta didik di sekolah agar sesuai dengan peraturan dan tata tertib sekolah.

Dalam upaya merealisasikan nilai-nilai positif yang mendasari dalam pengembangan budaya organisasi sekolah diperlukan suatu strategi internalisasi agar nilai-nilai positif yang diyakini oleh sekolah tersebut dapat tertanam dan melekat dalam diri peserta didik. Internalisasi merupakan proses menanamkan keyakinan, sikap dan nilai yang dilakukan secara sengaja yang menentukan tingkah laku yang diinginkan bagi suatu sistem yang mendidik sesuai dengan tuntunan menuju terbentuknya kepribadian yang berkarakter (Na'imah, 2014).

Temuan penelitian tentang strategi internalisasi nilai-nilai positif dalam pengembangan budaya organisasi sekolah yang dilakukan oleh SMP GCS sejalan dengan pandangan Susilo (2016) bahwa strategi internalisasi dan penekanan nilai-nilai positif(karakter) dapat dilakukan baik dalam pembelajaran maupun dalam kebiasaan sehari-hari di sekolah karena pada hakikatnya pembentukan budaya berawal dari kebiasaan. Lebih lanjut dikatakan contoh bentuk pembiasaan yang dapat diterapkan bagi peserta didik antara lain melalui: pembiasaan untuk melakukan doa sebelum memulai pelajaran, menerapkan budaya $5 \mathrm{~S}$ (salam, sapa, senyum, sopan, santun), berperilaku cinta lingkungan dengan menjaga kebersihan serta melakukan penghijauan, menghargai perbedaan pandangan dan pendapat, bertanggung jawab atas hasil kerjanya, dan lain-lain termasuk pula dapat dilakukan melalui kegiatan internal 
sekolah serta kegiatan ekstrakurikuler sekolah. Sekolah harus dapat menjadi wadah yang mendukung keterlaksanaan pendidikan budaya dan karakter, dan untuk itu sekolah harus dikondisikan sebagai pendukung kegiatan yang mencerminkan kehidupan nilai-nilai budaya dan karakter yang diinginkan. Pengkondisian dimaksud menurut Wibowo (2012) adalah mengkondisikan suasana sekolah sedemikian rupa untuk mendukung terwujudnya internalisasi nilai karakter ke dalam diri peserta didik.

Zainal \& Sujak (2011) menyatakan pembentukan budaya sekolah yang baik dapat dilakukan melalui berbagai upaya yang dirancang dan dilaksanakan secara sistematis untuk membantu peserta didik memahami nilai-nilai perilaku manusia yang berhubungan dengan Tuhan Yang Maha Esa, diri sendiri, sesama manusia, lingkungan dan kebangsaan yang terwujud dalam pikiran, sikap, perasaan, perkataan, dan perbuatan yang berdasarkan dari norma-norma agama, hukum, tata krama, budaya, maupun adat istiadat yang dianut oleh masyarakat. Kondisi sekolah yang mendukung (kondusif) akan menjadikan proses penanaman nilai-nilai positif yang diyakini sekolah menjadi lebih mudah. Sarana fisik yang disediakan sekolah antara lain pemasangan slogan-slogan di ruang kelas, simbol-simbol serta aturan tata tertib sekolah yang di tempelkan di tempat yang strategis agar mudah dibaca oleh peserta didik. Strategi tersebut sebagaimana dinyatakan Schein (dalam Maslowski, 2001) sebagai artefak dan praktik. Melalui budaya artefak, asumsi dasar, nilai dan norma lingkungan sebuah sekolah dapat divisualisasikan. Artefak dan praktek antara lain diwujudkan melalui: simbol-simbol, ritual, serta perilaku yang terlihat dan terdengar (visible and audible behavior patterns).

Dalam upaya mengembangkan budaya organisasi sekolah, masing-masing komponen sekolah dapat memainkan peran yang berbeda-beda. Mereka bertanggung jawab terhadap kelangsungan struktur dan kegiatan-kegiatan sekolah, berbagai prosedur dan kebijakan, program-program dan sumberdaya, serta standar dan aturan yang berlaku di sekolah. Mereka juga memainkan peran yang pokok dalam membentuk budaya sekolah dengan cara mengomunikasikan visi dan misi sekolah, mengartikulasikan dan memelihara nilai, norma, dan kebiasaan-kebiasaan yang positif, serta menghargai setiap capaian yang diperoleh warga sekolah (Deal \& Peterson, 2009). Sudrajat (2019) menjelaskan untuk membantu palaksanaan program budaya sekolah yang berbasis karakter terpuji, pihak sekolah atau kepala sekolah hendaknya membentuk tim pengawal budaya sekolah dan karakter. Tim ini bisa melibatkan atau terdiri dari unsur pimpinan sekolah, guru, guru bimbingan dan koseling, dan perwakilan orang tua/wali peserta didik. Tim ini bertugas untuk menentukan prioritas nilai, norma, kebiasaan-kebiasaan karakter tertentu yang akan dibudayakan dan ditanamkan di lingkungan sekolah serta bertugas untuk merencanakan dan menyusun program pelaksanaan pembudayaan dan penanaman karakter di lingkungan sekolah dalam rentang waktu tertentu untuk kemudian secara periodik melakukan pertemuan untuk mengkoordinasikan dan melakukan evaluasi terhadap semua kegiatan dan perkembangan pelaksanaan program pembudayaan karakter di lingkungan sekolah.

\section{Faktor Pendukung dan Kendala dalam Pengembangan Budaya Organisasi Sekolah}

Faktor pendukung dalam pengembangan budaya organisasi sekolah di SMP GCS, meliputi: (1) Sekolah memiliki sumber daya manusia (kepala sekolah, guru dan tenaga kependidikan) yang taat akan agama; (2) Tersedianya berbagai sarana prasarana untuk menunjang kegiatan budaya organisasi sekolah yang "religius" yang dimiliki oleh sekolah, seperti: ruangan aula yang representatif dan tersedianya peralatan musik untuk mendukung kegiatan ibadah puji-pujian; (3) Tersedianya tim Satgas pengawal budaya sekolah, (4) Kerjasama yang solid antara sekolah dan orang tua dalam merealisasikan program-program pengembangan budaya organisasi sekolah yang diwujudkan dalam program Bible Camp dan Family Day. Para orang tua memberikan dukungan baik materiil maupun non materiil untuk keterlaksanaan program tersebut. Sedangkan faktor yang menjadi kendala dalam pengembangan budaya sekolah, meliputi: (1) Karakter peserta didik yang variatif disebabkan background keluarga yang beragam, khususnya dalam hal ketaatan dalam beragama; (2) belum optimalnya control orang tua terhadap penggunaan gadget (smartphone) di luar jam sekolah. Dalam upaya meminimalisir berbagai kendala yang ada, sekolah melakukan koordinasi dengan komite sekolah agar senantiasa mengingatkan dan memberikan pemahaman kepada para orang tua bahwa mereka harus dapat menjadi contoh dan suri tauladan (role model) yang baik bagi anak-anak mereka dan meminta kepada orang tua untuk melakukan 
pengontrolan jam belajar dan bermain anak di rumah. Peran orang tua sangat menentukan terhadap tumbuh kembang anak mengingat terbatasnya waktu yang dimiliki sekolah untuk melalukan pembinaan dan pemantauan terhadap kehidupan peserta didik selain hanya pada jam sekolah.

Temuan penelitian tentang faktor pendukung sekaligus kendala yang dihadapi dalam pengembangan budaya organisasi sekolah di SMP GCS sejalan dengan pendapat Sartono, dkk (2015) bahwa keberhasilan program budaya sekolah tak lepas dari dukungan seluruh stakeholder. Lestari dan Sukanti (2016) menyatakan seluruh komponen pendidikan yang ada di sekolah, seperti: pengelolaan sekolah, pemberdayaan sarana prasarana, isi kurikulum, proses pembelajaran dan penilaian, kegiatan ko-kurikuler, pembiayaan serta etos kerja seluruh warga sekolah tidak akan dapat berperan maksimal tanpa adanya dukungan/pelibatan dari pemangku kepentingan. Sekolah dapat merealisasikan program kolaborasi antara guru dan peserta didik baik dalam proses belajar mengajar maupun kepemimpinan, serta kolaborasi antara sekolah dengan masyarakat dalam memecahkan berbagai permasalahan yang dihadapi sekolah dan hal ini merupakan pengembangan kultur yang positif dan efektif bagi semua pihak (Fletcher dalam Siswanto, 2017). Untuk itu Lickona (2008) menyarankan pendekatan yang bisa digunakan adalah dengan mengusulkan kepada orang tua tentang nilai-nilai karakter apa yang akan/harus dikembangkan sekolah dan mengajak para orangtua untuk berkomitmen mencapai tujuan pendidikan. Dengan terjalinnya hubungan timbal balik yang harmonis akan memungkinkan munculnya kreativitas serta dinamika kedua belah pihak yang inovatif, sekaligus pula dapat memadukan kehidupan sekolah dan kehidupan masyarakat (Muldiyah, 2011).

\section{Peran Stakeholder dalam Mendukung Pengembangan Budaya Organisasi Sekolah}

Peranan yang dilakukan stakeholder dalam mendukung pengembangan budaya organisasi sekolah di SMP GCS, yaitu: (1) Support dari para orang tua peserta didik, baik materiil maupun non materiil dalam program Bible Camp dan program Family Day serta program-program sekolah lainnya, dan (2) Support dari pihak Gereja Kalimantan Evangelis (GKE) Kalimantan Tengah, dalam penyediaan Pendeta untuk pelaksanaan ibadah harian dan music player untuk mengiri ibadah puji-pujian. Temuan penelitian tentang peranan yang dilakukan stakeholder SMP GCS dalam mendukung pengembangan budaya organisasi sekolah sejalan dengan pendapat Kholis, dkk (2014) bahwa sesungguhnya bentuk pelibatan yang dapat dilakukan oleh stakeholder atau masyarakat yang berkepentingan dengan sekolah dapat direalisasikan dalam berbagai bentuk dukungan, antara lain: melalui partisipasi aktif dari para orang tua dan masyarakat dalam berbagai program yang dirancang oleh sekolah maupun program rancangan bersama dengan orang tua/masyarakat. Salah satu upaya agar terbinanya hubungan yang efektif antara sekolah dengan para orang tua peserta didik manakala sekolah melakukan komunikasi dengan orangtua secara jelas dan sesering mungkin dengan memperhatikan dan mengembangkan prinsip: (1) ciptakan sekolah yang terbuka, menolong, dan bersahabat, (2) beri penghargaan kepada mereka (orangtua) yang telah menunjukkan dedikasi dan sumbangsih bagi kemajuan pendidikan di sekolah..." (Bacharach, 1990). Stakeholder merupakan "penginput" sekaligus pengguna dari hasil pendidikan yang diperoleh dari sekolah. Oleh karenanya, penyelenggaraan pendidikan itu sendiri tidak terlepas dari pentingnya keterlibatan stakeholder di dalamnya. Berbagai peran keterlibatan tersebut dapat diwujudkan, terutama dalam memberi dukungannya di dalam kelancaran penyelenggaraan pendidikan di sekolah, baik yang bersifat materi maupun non materi (Agung, 2012).

\section{SIMPULAN}

Berdasarkan hasil penelitian dan pembahasan yang telah diuraikan sebelumnya dapat disimpulkan bahwa budaya organisasi sekolah dapat dikembangkan dengan cara mensarikan nilai-nilai positif yang bersumber dari ajaran agama. Nilai-nilai positif yang terdapat dalam ajaran agama diyakini kebaikannya di mata manusia karena bersumber dari Tuhan Yang Maha Esa, sekaligus pula secara tidak langsung akan menjadi penciri sekolah dan meningkatkan citra baik sekolah di masyarakat. Dalam upaya menginternalisasikan nilai-nilai positif agar tertanam dan melekat dalam diri peserta didik yang pada akhirnya akan menjadi budaya organisasi sekolah, strategi yang dapat dilakukan adalah dengan merealisasikan nilai-nilai positif tersebut kedalam berbagai kebijakan dan program sekolah 
baik yang disusun oleh sekolah maupun bersama dengan stakeholder, seperti: program pembiasaan melalui kegiatan sekolah yang terprogram baik kurikuler maupun ekstrakurikuler, penyusunan dan penegakkan berbagai peraturan dan tata tertib sekolah yang dalam implementasinya dilakukan oleh Satgas pengawal budaya sekolah untuk memonitor dan mengawal jalannya kehidupan peserta didik di sekolah, pengkondisian sarana fisik sekolah melalui artefak dan praktek yang divisualisasikan melalui simbol-simbol, ritual, dan perilaku yang terlihat dan terdengar (visible and audible behavior patterns), serta dukungan dari stakeholder yang diwujudkan melalui partisipasi aktif dalam mendukung berbagai program pengembangan budaya organisasi sekolah.

\section{DAFTAR RUJUKAN}

Agung, I. 2012. Strategi Mengembangkan Organisasi Pembelajar di Sekolah. Jakarta: Bee Media Indonesia.

Amalia, F. N., Mashita, N., \& Tri, W. 2017. Fungsi Guru dalam Pembentukan Karakter Peserta Didik di Sekolah. Online, tersedia di: http://ap.fip.um.ac.id/wp-content/uploads/2017/12/Faizah-Nur-Amalia-Nurida-MashitaNovita-Tri-W..pdf. Diakses tanggal 20 Desember 2019.

Atika., Nugroho, P. J., \& Sumarnie. 2019. Pengembangan Budaya Sekolah Berbasis Katolik. Equity in Education Journal (EEJ), Vol. 1(1), 1-10.

Bacharach. S. B. 1990. Education Reform: Making Sense of It All. Boston: Allyn and Bacon.

Bafadal, I. 2003. Peningkatan Profesionalisme Guru Sekolah Dasar: Dalam Rangka Manajemen Peningkatan Mutu Berbasis Sekolah. Jakarta: Bumi Aksara.

Bakri, S. 2010. Strategi Kepala Sekolah dalam Membangun Budaya Religius di Sekolah Menengah Atas Negeri (SMAN) 2 Ngawi. Tesis tidak diterbitkan. Malang: Universitas Islam Negeri Malang (UIN Malang).

Bukhori, I., \& Anita, N. 2009. Pengaruh Kultur Sekolah Terhadap Motivasi Belajar Peserta didik Melalui Kinerja Guru. Jurnal Penelitian Kependidikan, 19(2), 60-80.

Deal, T. E., \& Peterson, K. D. 2009. Shaping School Culture: Pitfalls, Pradoxes, \& Promises. Second Edition. San Francisco: Jossey-Bass.

Departemen Pendidikan Nasional (Depdiknas). 2003. Pengembangan Budaya dan Iklim Pembelajaran di Sekolah (Materi Diklat Pembinaan Kompetensi Calon Kepala Sekolah/Kepala sekolah). Jakarta: Direktorat Tenaga Kependidikan Direktorat Jenderal Peningkatan Mutu Pendidik dan Tenaga Kependidikan.

Dewi, M. P . R. 2015. Internalisasi Budaya Sekolah Berbasis Islam (Studi Kasus di Madrasah Tsanawiyah Negeri 1 Model Palangka Raya). Skripsi tidak diterbitkan. Universitas Palangka Raya: Program Studi Manajemen Pendidikan.

Emzir. 2014. Metode Penelitian Kualitatif Analisis Data. Jakarta: Rajagrafindo Persada.

Hafidhuddin, D., \& Tanjung, H. 2003. Manajemen Syariah dalam Praktik. Jakarta: Gema Insani

Hermino, A. 2013. Asesmen Kebutuhan Organisasi Persekolahan. Jakarta: Gramedia Pustaka Utama.

Hidayat, K. 2010. Kultur Sekolah. Online, tersedia di: http://www.uinjkt.ac.id/index/php/category-table/1456membangun-kultur-sekolah.html. Diakses 19 Desember 2019.

Hotimah, H., \& Hariyati, N. 2009. Budaya Sekolah di SDIT Ustman Bin Affan Surabaya. Inspirasi Manajemen Pendidikan, Vol. 6(1), 1-7.

Husni, M. 2015. Budaya Sekolah dan Peningkatan Mutu Pendidikan. Online, tersedia di: https://www.academia. edu/28569029/Budaya_Sekolah_Dan_Peningkatkan_Mutu_Pendidikan. Diakses pada 25 Agustus 2018.

Jones, R. 1996. The School Culture Inventory: A Tool for Identifying Values, Setting Goals and Bringing about School Improvement. Education Canada, 36(4), 6-10.

Kasali, R. 2007. Re-code your Change DNA: Membebaskan Belenggu-Belenggu untuk Meraih Keberanian dan Keberhasilan dalam Pembaharuan. Jakarta: Gramedia Pustaka Utama.

Kholis, N., Zamroni., \& Sumarno. 2014. Mutu Sekolah dan Budaya Partisipasi Stakeholders (Studi Fenomenologi di Sekolah Konfensional MIN Tegalasri Wlingi Blitar). Jurnal Pembangunan Pendidikan: Fondasi dan Aplikasi, Vol. 2(2), 13-142.

Kosim, A. 2019. Internalisasi Pendidikan Karakter Berbasis School Culture. Jurnal Wahana Karya Ilmiah Pendidikan, Vol. 3(1), 240-251.

Lestari, P., \& Sukanti. 2016. Membangun Karakter Siswa Melalui Kegiatan Intrakurikuler, Ektrakurikuler dan Hidden Kurikulum di SD Budi Mulia Pandeansari Yogyakarta. Jurnal Penelitian, Vol. 10(1), 71-96.

Lickona, T. 2008. Educating for Character: How Our Schools Can Teach Respect and Responsibility. New York: 
Bantam Books Publishing History.

Maslowski, R. 2001. School Culture and School Performance. Netherland: Twente University Press.

Miles, M. B., Huberman, A. M., \& Saldana, J. 2014. Qualitative Data Analysis: A Methods Sourcebook. Edition 3. USA: Sage Publications. (Terjemahan Tjetjep Rohindi Rohidi, UI-Press).

Muhaimin. 2003. Arah Baru Pengembangan Pendidikan Islam Pemberdayaan, Pengembangan Kurikulum Hingga Redifinisi Islamisasi Pengetahuan. Bandung: PT. Remaja Rosda Karya.

Muhaimin., Suti'ah., \& Prabowo, S. L. 2009. Manajemen Pendidikan: Aplikasinya dalam Penyusunan Rencana Pengembangan Sekolah/Madrasah. Jakarta: Kencana.

Muldiyah, S. 2011. Kerjasama Sekolah dan Masyarakat dalam Meningkatkan Kualitas Pendidikan di Madrasah Aliyan Jamiyyatul Mubtadi Cibayawak Malimping. Online, tersedia di: http://repository.uinjkt.ac.id/dspace/ bitstream/123456789/2416/1/98019SITI\%20MULDIYAH-FITK.pdf. Diakses tanggal 19 Desember 2019.

Na'imah, T. 2014. Internalisasi Karakter Sosial melalui Budaya Sekolah. Artikel dipresentasikan pada Seminar Hasil Penelitian LPPM Universitas Muhammadiyah Purwekerto, Purwekerto, 6 September 2014 (206-212). (Prosiding).

Nasution, S. 1982. Berbagai Pendekatan dalam Proses Belajar Mengajar. Jakarta: Remaja Rosda Karya.

Rahayu, N. P., Nugroho, P. J., \& Berliani, T. 2009. Pembinaan Profesional Guru SD Daerah Terpencil. Equity in Education Journal, Vol. 1(1), 62-72.

Samsuri. 2011. Pendidikan Karakter Warga Negara. Yogyakarta: Diandra.

Sartono, I,. Muhadjir., \& Sumarno. 2015. Pendidikan Nilai Kebangsaan Melalui Budaya Sekolah di SMA Taruna Nusantara dan SMA Kolese De Britto. Jurnal Pembangunan Pendidikan: Fondasi dan Aplikasi, Vol. 3(2), 142-150.

Siswanto. 2017. Apa dan Bagaimana Mengembangkan Kultur Sekolah. Klaten: Bosscript.

Sonhadji, A. 1994. Misi, Strategi, dan Kendala Penelitian Kualitatif. Makalah disam-paikan dalam Lokakarya Penelitian Kualitatif Tingkat Lanjut Angkatan III, 24 Oktober 1994 s.d 29 Desember 1994, Pusat Penelitian IKIP Malang.

Sonhadji, A. 2012. Manusia, Teknologi, dan Pendidikan Menuju Peradaban Baru. Malang: Penerbit Universitas Negeri Malang.

Sudrajat, A. 2019. Membangun Budaya Sekolah Berbasis Karakter Terpuji. Online, tersedia di: http://staffnew. uny.ac.id/upload/131862252/penelitian/Membangun+Kultur+Sekolah+Berbasis+Karakter.pdf. Diakses 19 Desember 2019.

Susilo, M. J. 2016. Strategi Menciptakan Budaya Sekolah yang Kondusif melalui Paradigma Sekolah-Sekolah Unggul Muhammadiyah. Artikel dipresentasikan pada Simposium on Bilogy Education (Symbion) FKIP Universitas Ahmad Dahlan, Yogyakarta, 27 Agustus 2016 (567-576). (Prosiding).

Tilaar, H. A. R. 2000. Paradigma Baru Pendidikan Nasional. Jakarta: PT. Rineka Cipta.

Tirtahardja, U., \& Sulo, S. 2005. Pengantar Pendidikan. Jakarta: PT. Rineka Cipta.

Wibowo, A. 2012. Pendidikan Karakter: Strategi Membangun Karakter Bangsa Berperadaban. Yogyakarta: Pustaka Pelajar.

Wibowo. 2010. Budaya Organisasi: Sebuah Kebutuhan untuk Meningkatkan Kinerja Jangka Panjang. Jakarta: PT Raja Grafindo Persada.

Zainal, A., \& Sujak. 2011. Panduan dan Aplikasi Pendidikan Karakter. Jakarta: Gaung Persada Press. 